\title{
Staying Politically Active in Exile: Kurdish Activists in Germany
}

\author{
Sevil Çaker-Kılınçoğlu
}

\section{Introduction}

Embarking on self-initiated or forced migration is a difficult decision to make, especially for those who are involved in political and social activism in contexts that are marked by authoritarian regimes, ethnic conflicts, and civil wars. For many activists and intellectuals, the dilemma poses itself as one of either "stay and fight at high risk" or "flee and find other ways to fight". The condition of exile and exilic activism, indeed, have a long history and have been experienced by members of many generations of activists from various backgrounds. One can easily think of numerous activists and intellectuals from anti-imperialist, anti-colonialist, anti-capitalist, liberation and civil rights movements, not only in the Middle East but also all around the world, who had to flee their countries throughout the $20^{\text {th }}$ century; including those who fled from Nazi Germany and other fascist regimes. In addition to this, the members of stateless nations, such as Palestinians, Tamils and Kurds, have organized themselves in exile, and constituted important diasporas. All the aforementioned groups have organized themselves, mobilized others, created transnational solidarity networks, increased awareness, and raised funds abroad to support political movements at home. Some have even established so-called parliaments or governments in exile (Bell/Dennen 1944). 
With the current increasing appeal of authoritarian governments and their repressive methods against minorities, marginalized groups and political opponents, as well as prolonged civil wars, the number of members of such groups leaving their countries is soaring. Therefore, it is likely that we, as scholars interested in social movement and migration studies, will encounter the phenomenon of 'activism in exile' in the near future more than ever. However, whether we have a nuanced theoretical approach or a conceptual framework to analyze this not-so-new phenomenon is debatable.

Therefore, this chapter aims to shed some light on the experiences of migrant political activists who had been organized in civil, political and human rights movements under repressive regimes and fled their countries as a result of political persecution. In order to do this, I will compare the cases of two Kurdish migrants from Turkey and Iran who sought refuge in Germany recently after suffering persecution in their home countries. I conducted several biographical narrative interviews with the two Kurdish refugees during 2019 as part of the research project titled "Biographies of migrants from Syria and West Africa in Brazil and in Germany", ${ }^{1}$ in order to compare and analyze the experiences and positioning of the Kurds in Germany. ${ }^{2}$

In this study, I benefit from, and hope to contribute to, the methods developed in two research fields, namely social movement studies (SMS) and biographical research. While drawing on research in SMS that prioritizes the emotions, motivations and perceptions of the actors from a social constructivist perspective (ÇakırK1lınçoğlu 2019; Della Porta 1995; Goodwin/Jasper 2006; Wood 2003), I also resort to the analytical methods of biographical research, such as biographical narrative interviews and critical analysis of life stories and life histories (Rosenthal 2006, 2018). With the comparison of the cases, my main objective is to take research on actors further and thereby challenge homogenizing views on migrants and refugees in general, and participants in collective action in exile in particular. The comparative discussion of the two cases highlights the similarities and differences in the life histories and self-presentations (Rosenthal 2018: 175 ff.) of Kurdish migrants in Germany. The analysis of the cases before the backdrop of the socio-political context of their home countries and the Kurdish diaspora in Germany illustrates the prominent impacts of 1) configurations in the home countries, 2) the presence of an influential transnational social movement organization in the host country, and finally, 3) the nature of the migration experience on the formation and transformation of activist biographies in exile, even under similar conditions.

\footnotetext{
1 "Biographies of migrants from Syria and West Africa in Brazil and in Germany. Processes of inclusion and participation in the context of so-called irregular migration" (RO 827/21-1; February 2019 - January 2022), funded by the German Research Foundation (DFG) under the supervision of Prof. Dr. Gabriele Rosenthal (University of Göttingen, Germany).

${ }^{2}$ I also conducted participant observations among the Kurdish community in Germany which informs my comments and hypotheses in this study.
} 
In the following sections, I reconstruct the conditions, and the individual and collective trajectories, that play a significant role in the configuration and persistence of activist biographies in the context of Kurdish refugees and migrants in Germany in general, and in the cases of the two Kurdish refugees from Turkey and Iran in particular. This chapter consists of three parts dealing with the question of activism and activists in exile. In the first part, I give some background information on the history of this social phenomenon, i.e. activism in exile. After this, I focus on the history and present state of the Kurdish question in the Middle East and its transnationalization through the migration of Kurds to Europe, especially to Germany. With this, I aim to describe and explain the conditions determining the formation of the Kurdish diaspora and to point out the general context in which the decisions and actions of the Kurds in Germany are influenced and shaped. I use the term diaspora, or Kurdish diaspora, as a general term to describe the collectivity formed by Kurdish migrants outside of their native land. Following Baser, Emanuelsson, and Toivanen (2015), I do not claim that it is a monolithic body. Yet, almost all Kurds, whether political exiles or economic migrants, who leave their homeland and migrate to Europe are associated with the Kurdish diaspora in one way or another. Thus, Kurdish political activism in exile is closely related to, if not determined by, the formation, structure, and positioning of the Kurdish diaspora. Since the life stories of the two Kurdish interviewees are told within, and thus heavily influenced by, this particular context, I dedicate a substantial part of the chapter to explaining it in detail. In the second part, I discuss the cases of two political refugees, with a particular focus on the differences and similarities in their life histories and selfpresentations, and offer some preliminary conclusions. Finally, I propose some suggestions for understanding the cases of these two migrants and for the future study of political activism by migrants.

\section{Activists in Exile: A Historical Phenomenon}

Exile as a political practice has historically been resorted to by both the political authorities and the activists or intellectuals themselves (Roniger/Sznajder 2009). While political authorities have often preferred to force their opponents into exile in order to pacify them or to remove the immediate threat, it has also been common for opponents and activists to initiate or continue their activism in exile in order to escape the repressive conditions in their home countries or increase the chances of success of their activism under more liberal conditions. Many European cities, such as Paris and London, have for centuries served as a hub where oppositional political activists and intellectuals seek refuge, gather together, and organize themselves. One can talk about a historical tradition of Middle Eastern and North African intellectuals and activists organizing themselves in the metropolitan cities of the West to initiate, support or sustain the oppositional movements in their home countries, as well as another trend in which those who have failed or been defeated flee to the West to 
settle, or to wait for the next opportunity. Throughout the modern history of the region, nationalists, communists, socialists, liberationists, separationists, ethnic and religious rights activists, or simply the advocates of democracy and human rights have experienced exilic conditions. In addition to Kurds, some of the well-known examples are Armenians and Palestinians (Sayigh 1987). Among the contemporary examples, the Iranian student movement against the Shah's regime was only able to organize in Europe and the U.S. during the 1960s and 1970s, and from the 1979 Revolution up until today many Iranians in diaspora have actively opposed the Islamic regime. Many members of the revolutionary and leftist organizations in Turkey had to flee and organize themselves in exile, especially after the 1980 military coup in the country. While they were able to return at some point to Turkey, once again the opposition to the current Turkish government, the AKP, is flourishing in exile, spearheaded by academics, intellectuals, journalists and artists. Despite the abundance of examples of diaspora populations and exiled communities with a history and tradition of political activism, the number of studies devoted to them is limited. Especially studies on the biographical and collective trajectories of people opting for an activist career are rare. However, not every member of these groups is able or willing to continue their political and social activities, at least not to the same extent and with the same intensity, in the countries to which they have fled. There are a number of factors complicating their new position and choices, including among others the character of their activism, political, social or familial conditions in the country of origin, and legal regulations in the country of destination. The last of these factors is closely related to the migration policies of the host countries. Of course, it is not possible within the limits of this paper to discuss the historical transformation or the current state of the relevant policies of Western countries vis-à-vis refugees and migrants. However, it suffices to note that these policies have come to play a significant role in the way political activists have seen and used exile as a strategic position for their fight (Østergaard-Nielsen 2003).

According to most estimates, Kurds form the largest stateless ethnic group in the world (Tas 2017) and one of the largest ethnic groups in diaspora. ${ }^{3}$ They have come to form strong and active communities in Sweden, France, the Netherlands, the U.S., the UK, and even Japan (Baser/Emanuelsson/Toivanen 2015: 137). It can be said that one of the most prominent cases facing the dilemma of activism in exile, or in diaspora, is that of the Kurds, especially those among them who have in one way or another been involved in Kurdish political activism in the countries they come from.

The territories of historical Kurdistan, have been divided up by the establishment of national borders and now belong to four countries: Turkey, Iran, Iraq and Syria. All these countries have at some point in their history been ruled by authori-

\footnotetext{
${ }^{3}$ Since Kurds are registered as Turkish, Iranian, Iraqi or Syrian citizens respectively in the countries they migrate to, and there is no reliable census in Europe, the U.S. or Canada, it is not possible to know their exact numbers. Yet most sources estimate that there are 2 million Kurds in diaspora. For example, see: https://www.institutkurde.org/kurdorama/ <22.05.2020>.
} 
tarian regimes. Furthermore, in the hegemonic political discourses Kurds have been considered a threat to the national unity of the respective countries and subjected to various forms of repression and violence. The level and extent of violent and repressive policies have been contingent on both the character of the authoritarian regimes and that of the Kurds' socio-historical configurations in these countries. These repressive policies have often resulted in the migration or escape of numerous Kurds to Europe, and thus in the constitution of a large diaspora in Europe in general and in Germany in particular.

There are currently around one million Kurds living in Germany, most of them from Turkey (Baser/Emanuelsson/Toivanen 2015: 133). Besides its large size, another major characteristic of the Kurdish diaspora is its rich diversity, originating from cultural differences in their countries of origin, religious and sectarian ${ }^{4}$ belongings, languages spoken, and differences in the host countries in which they are currently settled. Finally, in addition to its size and diversity, the Kurdish diaspora is also known for its vigorous political activism in exile, qualifying as a well-organized social movement (Eccarius-Kelly 2002: 95). All these specific and general characteristics of the Kurdish diaspora have a definitive influence on the experiences and positioning of its members in the countries and societies in which they are currently settled; however, I will focus in this chapter on their impact on social and political activism, which is closely related to the conditions determining their migration and diaspora formation in Europe.

\section{Kurdish Migration to Europe and Germany}

There has been a flow of Kurdish migrants to Europe since the middle of the $20^{\text {th }}$ century. While the Kurds from Turkey were the earliest and most numerous among the Kurdish migrants arriving in Germany, those in Iran, Iraq and Syria followed suit due to wars and direct attacks against the Kurdish population by the authoritarian regimes of those countries. In addition to regular systemic persecution and repression, the most significant events forcing the Kurds to flee their homes in high numbers in the second half of the $20^{\text {th }}$ century were the Iranian revolution (1979), the Iran-Iraq war (1980-1988), the Anfal and Halabja (1988) ${ }^{5}$ attacks and repression by the Saddam regime during the 1990s, the war between Turkish armed forces and the Kurdistan Workers' Party (PKK) in the same decade, and the Syrian war since 2011. I will focus here on developments in Turkey and Iran, because they are the

\footnotetext{
${ }^{4}$ Kurds are predominantly Muslim but belong to different sects of Islam; while most of them are Sunni, there is a large Alevi Kurdish population in Turkey. In addition to Sunni Kurds in Iran there are also Shi'i Kurds. There are also other religious practices among the Kurds such as Yezidism, and Ahl-iHaqq. For more details see Bruinessen 1991.

${ }^{5}$ During the last years of the Iran-Iraq war, Saddam Hussain launched a brutal attack against Kurds in Northern Iraq known as the Anfal Campaign. As a part of the campaign, a chemical attack killed 5,000 Kurds in Halabja in March 1988. The total number of Kurds killed between February and September 1988 was estimated to be between 50,000 and 100,000 (Human Rights Watch 1993: xiv).
} 
countries from which my interviewees come and where the numbers of Kurds are highest -14.7 million and 8.1 million respectively. What is also noteworthy is the scarcity of studies on Kurds coming from countries other than Turkey. Almost all studies on the Kurdish diaspora in Europe focus solely on Kurds from Turkey. In addition to their comparatively greater numbers, the politically more active character of Turkey's Kurds, mostly due to mobilization by the PKK in Europe, seems to have played a role in this research bias.

Kurds from Turkey first began to come to Germany as a part of the labor agreement between Turkey and Germany at the beginning of the 1960s. As Turkish citizens, Kurds were seen as a subcategory of Turkish guest-workers. Yet, the character of Kurdish migration changed after the military interventions in 1971 and 1980 in Turkey, and took on a political nature with the arrival of more asylum-seeking Kurds due to the violent political repression of the Kurds by the Turkish regime. The 1990s was marked by intense clashes between the PKK and the Turkish army. Internal forced migration of Kurds from their villages in Turkey, in addition to the killing and disappearance of thousands, contributed to the increase in regular migration of Kurds from Turkey to Germany in the early 2000s. For example, thousands of villages were destroyed, as well as the resources sustaining life in these villages, during the war between the PKK and the Turkish army. A total of 905 villages and 2.523 settlements were evacuated, according to an investigation by the Turkish parliament in 1997 (Bruinessen 1999; fn. 5).

In Iran, too, the 1980s marked a critical period for the Kurdish people, as the civil war after the 1979 Revolution mostly took place in Iranian Kurdistan. Right after the Revolution, Khomeini "declared jibad against the Kurds, accusing them of acting against the Revolution" (Akbarzadeh et al. 2019, 5). He never agreed to negotiate with the leaders of the Kurdistan Democratic Party (KDP), even before the war with Iraq, and eventually killed thousands of Kurds (Ahmadzadeh/Stansfield 2010). Since then, the policy of the Iranian regime in respect of the Kurds in general, and Kurdish political movements in particular, has been one of brutal repression and strict control, although some level of toleration was occasionally granted during the reformist governments of Khatami (1997-2005) and Rouhani (since 2013) (Soleimani/Mohammadpour 2019). These and other catastrophic events have led to an internationalization of the Kurdish question through the transnational migration of Kurds in search of safety. What began as voluntary or economic migration from Turkey in the 1960s has turned into the forced migration of Kurdish people, culminating in the creation of a Kurdish diaspora in Europe as the "fifth part of Kurdistan" (Bruinessen 2015: 126).

\subsection{Kurdish Diaspora: A Well-Organized Non-State Political Actor}

While Kurds have faced many difficulties in the diaspora, such as lack of recognition of their separate ethnic identity, or precarious migratory conditions, several events, mostly in their home region, have contributed to the consolidation of their collective 
memory and identity. The first and foremost event was the foundation of the PKK in 1974 in Turkey. With the 1990s, the PKK began to dominate Kurdish movements in Europe, and especially in Germany (Lyon/Uçarer 2001: 933 ff.). Then, in 1988, the Halabja massacre by Saddam symbolized for Kurds the repression and the atrocities to which Kurds have been subjected under authoritarian regimes. The arrest of Abdullah Öcalan, the leader of the PKK by Turkey in 1999, was another turning point, not only in the political organization, but also in the collective memory of the Kurds in general, as well as those in diaspora. Obviously, the critical events which took place in their home countries influenced the collective memory and the political mobilization of Kurds in the diaspora, and the way in which Kurds are perceived in international public opinion and in the societies of their host countries. For example, events like the recognition of a Kurdish Regional Government (KRG) in Iraq in 2003, and YPG's war against ISIS have increased both their international visibility and the legitimacy of the Kurdish political struggle at home. However, even though events such as the fate of the Yezidis in Iraq, and the defeat of the ISIS by Kurdish forces in Syria have raised public awareness and sympathy for the Kurdish cause, Kurds in general are perceived with ambivalence in Europe. This is mostly related to the widespread public discourse and the policy of the "fight against terrorism" in Western countries. Thus, the image and the activities of the PKK abroad, at least until the 2000s, played an important role in this negative perception (Lyon/Uçaner 2001: 937).

As is commonly accepted in the literature on social movements, the success of a movement's transnationalization, in other words transnational activism, depends on the movement's ability to align itself with dominant frames such as justice, human rights, freedom of speech, ethnic or religious rights, and so forth (Della Porta 2004: 2 ff.; Benford/Snow 2000; Smith 2002). Even the most legitimate armed resistance movements could not appeal to a transnational public with a discourse solely based on political violence. Therefore, after the capture of its leader, Öcalan, the PKK changed its discourse and adopted the strategy of aligning with these dominant frames. Consequently, the PKK's policies and discourses have begun to prioritize human rights abuses against Kurds or national minority rights in Turkey, rather than the right to self-determination, or the legitimacy of an armed struggle to achieve the independence of Kurdistan. In diaspora, too, the focus and objectives of the political movement have shifted towards democratic rights and equal citizenship (EccariusKelly 2002: $91 \mathrm{ff}$.). Nevertheless, the fear of being labeled as 'supporters of terrorism' and criminalization is real for many members of the Kurdish diaspora, which discourages them from becoming involved in political activism.

Against all odds, the Kurdish diaspora has succeeded in establishing social and political organizations, initially concerned with issues back home, but increasingly because of their problems and objectives in the host countries. Currently, there is a huge number of organizations, associations, networks and institutes that Kurds have established throughout Europe, such as the Kurdish Institute of Paris and Brussels. However, the most influential political organizations usually have direct or indirect 
ties with the PKK and thus with the Kurds of Turkey; for example, the European Kurdish Democratic Societies Congress, the Kurdistan National Congress, the Kurdish Parliament in Exile in Europe, and the Demokratisches Gesellschaftszentrum der KurdInnen and KOMKAR in Germany. ${ }^{6}$ Even though Kurdish political organizations have flourished in European countries, especially in Belgium, they operate under strict state surveillance in Germany because of their alleged ties to the PKK (Bundesamt für Verfassungsschutz 2019), as I will show in the following section.

\subsection{Germany's Policy with Regard to the Kurdish Question}

Germany has the highest number of Turkish and Kurdish migrants in Europe and has naturally become one of the most important arenas of political activism for the Kurdish political movement. Germany's policy towards migrants and their problems, however, has been one of indifference, suppression or avoidance of conflict with the sending countries, from the time when it first began to accept "guest"workers in the 1960s to this day (Eccarius-Kelly 2002: 103 ff.). As a result of its resistance to defining itself as a migration society, Germany has followed this policy in the face of the Kurdish question, too, which has gradually become a domestic issue of its own (Baser 2014). Yet, what is really significant in the case of Kurds in Germany is that they are mostly from Turkey, and mobilization by the PKK dominates both their position and public perception of the Kurds in Germany (Baser 2011: 18). By contrast, the organizations of Kurdish migrants from Iran, Iraq or Syria have very limited public visibility, and very limited influence on the practices of the Kurdish diaspora in Germany.

Furthermore, Germany has prioritized its relations with Turkey, a close ally of Germany for decades, in the face of demands by Kurdish migrants on its own territory. The economic and political interests of Germany have played an important role in Germany's position in the Kurdish question, such as trade relations with Turkey, to whom Germany sells substantial amounts of military equipment. This last point has contributed to the perception of Germany by the Kurdish diaspora as “Turkey's ally"; this view was epitomized by the PKK's declaration of Germany as its "second enemy" in 1992. In response, and as a result of Turkey's lobbying, the PKK was declared as a terrorist organization in Germany in 1993 (Baser 2014: 1 ff.).

Another destabilizing factor for the Kurds in Germany was clashes between ultra-nationalist Turks and PKK supporters throughout the 1990s, which contributed to the perception of the Kurdish issue as a domestic security concern by the German authorities. A suppressive approach to political demands has given way to heavy surveillance of Kurdish activists (ibid.: 8 ff.). Even though the Kurdish political

\footnotetext{
6 While some of these organizations are open about their ties to the PKK (see, for example, https://kcdk-e.com/en/), others are more discreet. For a report by the German intelligence service regarding these organizations and how they are seen by the German state, see: Bundesamt für Verfassungsschutz 2014.
} 
movement has come a long way since the violent protests in Germany after the arrest of Öcalan in 1999, increasing surveillance and bans on the images and symbols of Kurdish political organizations have rendered activism around the Kurdish cause riskier for members of diaspora and made them more reluctant to actively join protests and demonstrations. ${ }^{7}$

\section{The Cases of Baran and Azad: Two Kurdish Rights Activists from Turkey and Iran}

Baran was born in 1988 in Dersim (its official name is Tunceli), Turkey, to an Alevi family, as the youngest of five siblings. Dersim has a population which is predominantly Alevi and Kurdish, and its history is marked by active Kurdish resistance against the Turkish regime. Baran's father used to be politically active, but always discouraged his kids from getting involved in politics. Baran grew up in Amed (its official name is Diyarbakir) and came of age in the 1990s, a period which was defined, as pointed out above, by intense conflicts between the Turkish military and the PKK. The state of emergency was the rule in the Kurdish regions of Turkey in this period during which the Kurdish language and cultural manifestations were forbidden and many unsolved murders were reported. Baran remembered his childhood and teenage years as a traumatic experience but also as a normal part of the collective history of the Kurdistan region in Turkey which still continues today:

We had our fair share of pains, with a lot of traumas ... there were so many incidents, you're living in Kurdistan, Amed, there was nothing but incidents in Amed, as I said, I was three or five years old, in Newroz celebration in Amed, then it was not legal, in the streets, we were panzer children, what else. In 2006 incidents they killed people in front of our eyes. ... [in Amed] everyone knows someone whose son became a martyr; everyone knows someone who is murdered by the state.

In 2007 Baran began to study at the medical school in Istanbul after getting high scores in the university entrance exam. He continued his political activities while at university and was immediately targeted by right-wing groups in his dormitory, as well as by the police. The police not only violently suppressed demonstrations by the Kurdish students, but also targeted and arrested them when they were attacked by the ultra-nationalists. Once, he was personally attacked by a big group of ultranationalists when he was alone in the dormitory. After attempting to defend himself, he was arrested and was eventually thrown out of the dormitory. Because of harassment and persecution by the police, he decided to move to a university in Amed, which he described as a Kurdish city, in order to be able to study in a safer environ-

\footnotetext{
7 The bans are not limited to PKK activism, but are extended in practice to the symbols and activities of other Kurdish political and cultural organizations, such as pictures of Öcalan, flags of the YPG and YPJ, the Kurdish militia which fought against the ISIS in Syria, or Kurdish cultural events. The refusal of residency rights, and even deportation of Kurds as a result of such political activities, are reported in the media. See for example Schamberger 2020; Dangeleit 2018; Thamm 2019.
} 
ment. Despite the heavy presence of troops and security units, Amed was still considered a safe city for Kurdish students and political activists, due to the majority Kurdish population and the presence of an organized Kurdish movement. This is why he chose to study in a mediocre university in Amed, although he could easily enter any university with the score he got in the university entrance exam. Unfortunately, in Amed, too, he faced harassment, this time from the university professors who did not let him pass the oral exams despite his success in all the written ones, as well as from the police, including arrest and torture. To avoid this kind of persecution, he went abroad to study as an Erasmus student. When Baran finally finished his university education in 2015, he faced another round of persecution from the authorities who refused for ten months to give him clearance to be able to work as a medical doctor. When he was finally allowed to work, he was charged in court for attending a protest against hunger strikes in prisons organized allegedly by the PKK. In order to escape imprisonment, he first went to Northern Iraq; however, he did not like the social and cultural conditions there, finding them more 'backward' than in Turkey (for a case of Iraqi refugees experiencing strangeness in a different Iraqi region and in neighbouring Jordan see Becker/Hinrichsen in this volume). He came back to Turkey, risking being arrested at any moment. As a result of pressure by his friends and family members to leave, he decided to flee to Europe. After a long and difficult journey, which involved a long stay and detention in Greece, he arrived in Germany in 2018 via the so-called Balkan route. He has applied for asylum and is still waiting for the result of his application, and is meanwhile taking German language courses. He intends to work as soon as he gets the language certificate.

During the interviews with me, Baran presented himself as a determined, dedicated Kurdish rights activist who does not intend to stay in Germany permanently. He stressed that he only agreed to leave Turkey as a result of pressure by his friends; otherwise, he would have stayed and served the prison term to which he had been sentenced, as he said several times during the interview. He talked mostly about what needs to be done for the bigger cause of the Kurdish rights movement, rather than what would be good for him as an individual. Baran views the Kurdish movement in Turkey as a front to be defended at all costs, and thinks that he should be a part of it. He does not feel that he belongs to Germany and has no intention of settling down. He also argues that German racism is clever and subtle, whereas Turkish racism is stupid and derives from "Kurd-phobia". In his presentation, the Kurdish diaspora in Germany is criticized for being too submissive to the German authorities. Baran claims that the Kurds in Germany are neither assimilated nor integrated, but a weird combination of the two. According to him they are afraid of getting involved in political organizations, and very much pacified by the German security forces. He advocates more radical political activism in favor not only of Kurdish rights and autonomy, but also of the rights of migrants and marginalized groups in general. Baran participates in demonstrations in Germany organized by anti-fascist, leftist, and progressive movements, as well as Kurds, and he does voluntary work in NGOs 
working with refugees and migrants. About his life in Germany, what he told his brother in Turkey is telling:

I tell him not to come. For me, my profession is not important, what matters is my belonging, my identity, I was not born a doctor, I was born a Kurd. Everything else is secondary. If I was not convicted, even then, I was actually planning to stay in Amed, if it was not for my conviction, I would have stayed in Amed and sell simit [Turkish pretzels]. I would not have left there to them. These are more important. I will go back in a slight betterment of my situation. I don't care to earn a lot of money, stay in Europe. And I know life here, I can adopt to it, but still ...

While Baran has only been in Germany for a year and a half, the second person I present here is more "experienced" in Germany. As an Iranian Kurd, Azad was born in 1985 to a family with seven kids in a town in the Kurdistan province of Iran. He grew up in this small and very old town and went to Tehran only after passing the university entrance exam in 2004. He lost 24 of his relatives in the Kurdish armed struggle against the Iranian regime. His father, like other family members, was not interested in politics but his very close relatives were. Nevertheless, Azad remembers his childhood nostalgically.

I had a very happy childhood. I had many chickens, I took care of them, loved them.... We children threw stones at the Sepah, but it was a game for us, people told us that they were bad, we were kids, there were no real reasons.

Sepah is short for a branch of the Iranian Army, which is called "Army of Guardians of the Islamic Revolution" and was established right after the revolution by Khomeini to protect the regime inside the country, which has in practice meant the repression of ethnic and oppositional groups by all means possible. The Sepab has been very active in the Kurdistan region of Iran (Hourcade 2009: 59).

Azad studied urban planning and human geography for his undergraduate degree and then went on to do a Master's degree in politics. In the second year of the university he got involved in student activism, organized around human rights issues. He was active in a Kurdish rights movement, publishing a journal, and protesting against the government's policies. During the Green Movement ${ }^{8}$ protests during the 2009 presidential elections, he was arrested, tortured for six days, and kept in prison for five months. Soon after his release, he was sentenced to five years on dubious charges; the accusations were drug-related so that persecution based on his ethnic and political activism could not be proved. When he found out that he might get five more years of imprisonment, meaning ten years in total, he decided to go underground, hiding in relatives' houses for a short period of time before fleeing to Northern Iraq. He intended to stay there, but it soon became clear that he had no

8 What has come to be known as the Green Movement, an episode of protests, emerged just before the presidential elections in Iran in 2009, during which people were mobilized to overthrow Mahmoud Ahmadinejad, the then president of Iran. After he got elected, the protestors declared it had been a rigged election, with the well-known campaign "where is my vote". As a result, more than 100 protesters were killed and many more were arrested and tortured. 
future prospects there, because he could not find educational or professional opportunities to improve himself. So, after nine months, and as a result of increasing harassment of family members by the regime, including house raids and threats of arrest, he decided to apply for asylum in Germany in Iraq. His application was accepted promptly, in two weeks to be exact, and he traveled to Germany, and was placed in a camp at the end of 2011. Since his arrival in Germany, Azad has been continuing his graduate studies, working and volunteering in Kurdish rights organizations. One of the organizations in which he is still active is mostly interested in issues in Iranian Kurdistan, but also, for example, in violence against women in Northern Iraq, or the Afrin struggle in Syria. He suggested that they are following the line and politics of the HDP, a pro-Kurdish political party in Turkey. This is a significant statement because HDP represents the non-violent branch of the Kurdish movement and advocates democratic autonomous governance for Kurdistan, rather than separationist policies. One example showing the nature of their activism is their awareness-raising campaign against the killing of Kulbers, the food and goods smugglers in Iran. The minimum charge for this "crime" is two years imprisonment in Iran, but usually they are killed when caught in the act without a trial (UNPO 2020). About his life in Germany, Azad says he had no intention of going back to Iran, even though all his family members are still in Iran. But he admits that he still feels like an outsider in Germany:

When arrived for the first time, I didn't have any problems. I learned the language, could work, still do. So, in terms of normal life, I don't have any specific problems, but, well relations with this society is not easy ... you cannot go and easily be part of the society. In terms of activities one would like to do, for example, now, when I was in Iran, I used to work in a newspaper, we had an NGO, I was socially and politically active. But here it is really very difficult to undertake social and political activities. You're not part of the society. ... True that I live here, but my mind is still there [Iran].

\section{Similarities, Differences and Their Preliminary Implications}

There are striking similarities and differences in the ways in which Baran and Azad presented their life stories. Given the fact that the trajectories paving the way for their flight to Europe are very similar, there must be other factors that account for the differences, as I will try to explain in this section. The main questions I will focus on are: What are the general similarities and differences between the cases of the two Kurdish rights activists who have ended up as political refugees in Germany? How different are they in their perceptions of the Kurds, Kurdish rights movements in Germany, and German state and society? What kinds of political activism do they advocate? And finally, how do they view their role and their future in Germany?

Among the similarities, firstly, the constant persecution of their ethnic fellows by security forces, and the direct and indirect repression of their political and social activities both in Turkey and in Iran are, as I have mentioned, well-documented. 
Both Baran and Azad were initially targeted and persecuted by the security forces for their involvement in student activism at university. Again, very similarly, they were both arrested, tortured, tried and convicted on dubious charges to conceal persecution based on their ethnicity. To avoid imprisonment, they both fled to Northern Iraq and decided to leave this region for similar reasons resulting from the lack of social and cultural opportunities, as well as political pressures. This should not come as a surprise, since Kurds from Northern Iraq are themselves fleeing the country for similar reasons. Finally, they both wanted to come to Germany, following the example of other Kurds with similar political trajectories.

Besides these similarities, however, there are many differences in the cases of Baran and Azad. They obviously differ from each other in their perceptions, presentations, and political stances vis-à-vis the role and position of the Kurds in Germany, their relations with the German state and society, and the sorts of activism they advocate at present. To begin with, they exhibit very different styles during their weand self-presentations in the interviews. For example, Baran usually adopted an argumentative style when telling his life story, and frequently expressed his opinions on the Kurdish issue in Turkey. By contrast, Azad's account was more descriptive and informative; he recounted details and explained the context of events which involved the Kurds in Iran. Baran emphasized repression of the Kurds based on their ethnic and sectarian identities in Turkey in order to account for the way he was persecuted, while Azad resorted to the discourse of human rights abuses and repression of political dissent under the Islamic regime to describe both his ordeal and that of the Kurds in Iran. This divergence in the we- and self-presentations could be explained by the different socio-historical, political and biographical trajectories that influenced the lives of Baran and Azad. Yet, the following factors seem to stand out as a result of a preliminary analysis of the interviews with the two.

First of all, the fact that I belong to the established grouping of Turks in Turkey probably played a role in Baran's argumentative and assertive style during the interview. However, his tone and style did not change in the follow-up interviews, by which time he had found out that I am not a nationalist Turk with anti-Kurdish political leanings, but rather a Kurdish rights advocate. It is worth noting that I felt no such tension during my encounter with Azad, and the interview language might be significant here. Persian, which I speak, did not evoke any power dynamics in the way Turkish did; on the contrary, it seemed to provide a sense of familiarity, if not a commonality, during the interview. However, Turkish has historically been a means of oppression for the Kurds in Turkey in general, and for Baran personally, who had never learned to speak Kurdish due to these oppressive policies and felt bad about it. What was also striking in Baran's discursive style was the abundance of well-chosen political terms, which left me feeling as if I had interviewed the spokesperson of a Kurdish political party. This last point clearly indicates a very controlled we- and self-presentation by Baran.

Additionally, I argue that another factor can help to explain their diverging presentation styles. It has to do with disparities in the strength of the Kurdish move- 
ments and in the repressive character of the political regimes in the two countries they came from, Turkey and Iran. This is confirmed by the correlation between their narrative styles and the level of political activism they advocate for the Kurdish diaspora in Germany and in their home countries. At least on the level of his selfpresentation, Baran claimed to be dedicated to the Kurdish political movement. He viewed his future as a part of, and in line with, the movement and argued that the Kurdish diaspora in Germany should become more politically active. Azad presented a social activist profile. He is more interested in solving everyday problems and in achieving policy reforms that would help to improve the quality of life of the members of the Kurdish diaspora and Kurdish communities in his home region. As argued above, the reason for this divergence between the two cases, in addition to their biographical courses, has a lot to do with the social and political configuration of the Kurdish movements in Turkey and Iran. The Kurdish movement in Turkey has always been stronger than that in Iran for a number of reasons, including, but not limited to, the presence of an armed political organization, the PKK, for four decades. By contrast, the Kurdish political movement in Iran gradually lost its strength due to the civil war after the Revolution and then the Iran-Iraq war in the 1980s. Furthermore, the political regime in Iran has never hesitated to use brutal methods to repress any sort of Kurdish political movement, whereas in Turkey, the Kurds have been able to establish parties and claim their political, social and cultural rights, despite having constantly paid heavy prices. In short, the confidence and assertiveness, or lack thereof, in the discursive style of these two political refugees could be related to the socio-political configuration of the Kurdish population in their countries of origin.

Admittedly, this cannot be the whole story and there is indeed another dimension defining their choices and positionality in Germany. This is the social and political configuration of the Kurdish diaspora they belong to in their host country. The peculiarity of the Kurdish diaspora in Europe, as mentioned above, is its diversity, resulting from the partition of their native land, Kurdistan, among the territories of four countries. The partition of the Kurdish population has resulted in the separate development of each part as members of completely different nation states. They have grown apart from each other not only socio-economically, but also linguistically. As a result of the nationalist language policies of the aforementioned states, the Kurds in different regions have begun to speak Turkish, Persian and Arabic rather than their own language. These divergencies, in turn, have affected the positioning and experiences of the members of different parts of Kurdistan in diaspora, as well as the relations between them. Even though this is not a publicly acknowledged fact concerning the Kurdish diaspora, the practical repercussions of this power imbalance can be detected on various levels of their political activism and everyday lives. For example, an earlier study has shown that Kurds in Europe prefer to socialize with their fellow countrymen rather than with Kurds from other countries (Demir 2012). This phenomenon seems to be reinforced by the dominance of the PKK in the social and political spheres in the diaspora. Despite efforts to bring 
together the political organizations of a divided Kurdistan, as for instance in the Kurdistan National Congress, the Kurds from Turkey predominate in the political as well as the cultural arena, thanks to their numerical and organizational superiority. In short, these dynamics and disparities among the members of the Kurdish diaspora could explain why Baran seemed more self-confident, speaking from a relatively secure position, while Azad was more modest about the potential and impact of his individual or collective activism. Baran and Azad did not know each other, although they were living in the same small city, and they were not active in the same organizations. This not only shows the extent of fragmentation among the Kurds, but also eliminates the possibility of interaction and mutual influencing between the different groupings.

Another area in which Baran and Azad differed from each other is in their perceptions of German state and society, as well as of the role and objectives of the Kurdish movement in Germany. While Baran described Germans as racist and Germany as just another repressive state, Azad was more nuanced and tried to distinguish between different groups and contexts. Baran advocated an aggressive political struggle for the Kurds in diaspora, whereas Azad aimed to improve the civil and democratic rights of Kurds in Germany. Their dissimilar migration courses, and the time they have spent in Germany also seem to play a significant role in their differing perceptions and opinions in this regard. Azad's arrival in Germany was relatively quick and comfortable, compared to Baran's longer and precarious course of flight, and this difference must influence their judgements. Azad has been in Germany for a longer period of time than Baran, and has had more experiences with, and exposure to, German society. In addition to the length of time spent in Germany, the quality of life might have also affected their perceptions and opinions. Baran was still waiting for the result of his asylum application in a refugee camp where he had had many encounters with racism, while Azad had a secure legal status after what seemed to be a straightforward asylum process. Furthermore, Azad was settled in Germany and planning to start a family, while Baran, who is younger, seemed to have no such long-term plans. Maybe this explains why he was critical of settled Kurdish people who are law-abiding citizens in Germany and who are afraid to take risks, and why he prioritized the Kurdish struggle at home. Azad, on the other hand, was concerned with advancing his own career, besides his voluntary activities to help Iranian Kurds in Germany.

\section{Conclusion}

Clearly, to be able to draw more convincing conclusions we need more comparative case studies of Kurdish migrants coming from different countries, specifically from different socio-political constellations, in order to understand the experiences, choices and positionalities of different collectives of Kurds in Germany, as well as in other countries. The cases we have seen show that various aspects of their 
biographies influence their choices as members of a politically active diaspora, and similarities do not suffice to categorize them simply as ethnic Kurds in exile. For Baran and Azad, the following factors seem to have exerted the biggest influence on the formation and transformation of their activist biographies in exile: 1) the sociopolitical configurations in their home countries, 2) the presence of an influential social movement or organization in the host country, and finally, 3) the nature of their migration experience. What makes this conclusion particularly interesting is that they belong to an ethnic diaspora which has successfully presented a strong we-image, at least in the transnational context.

Therefore, I argue, first, that there is a need for more research on the trajectory of activism in the life histories of these actors, from their early experiences in their home countries to their current positioning in the host country. It is clear that their experiences and configurations back home have a more long-lasting effect on their biographies than is acknowledged in the mainstream literature. Second, on the meso level, the presence of an influential, established and transnationally active political organization is critical for the persistence of activist biographies throughout the temporal and spatial transitions of the actors. The role of the PKK is a good example. Lastly, the character of the migration experience, and the length of time spent in the host country, must be taken into account, besides the official status and biographical availability of the activists in exile. Although in the social movements literature, biographical availability as the "absence of personal constraints that may increase the costs and risks of movement participation, such as full-time employment, marriage, and family responsibilities" (McAdam 1986: 70) is considered among the main factors influencing participation of activists in contentious politics, the activism of migrants and refugees seems to demand us to look beyond that.

In conclusion, I would like to draw attention to the potential benefits of comparative studies in this context. The cases of Baran and Azad, as two Kurdish rights activists who fled from very similar circumstances in different countries and ended up in the same city, show that similarities on the macro and micro levels do not necessarily lead to similar results. The processual combination of multiple features on the micro, meso, and macro levels promises a great potential for understanding and explanation, while a comparative analysis helps us determine the most influential factors. Moreover, comparative analyses can also help us to identify differences within a collective that is assumed to be homogenous in mainstream representations. The comparative analysis presented here shows that the heavy presence and political influence of a meso-level organization, the PKK, has put the Kurds from Turkey in an advantageous position compared to Kurds from the other countries and contributed to the divergencies among a seemingly homogenous collective with a strong we-image. 


\section{References}

Ahmadzadeh, H./Stansfield, G. (2010): The Political, Cultural, and Military ReAwakening of the Kurdish Nationalist Movement in Iran. In: Middle East Journal, 64(1), 11-27.

Akbarzadeh, S./Ahmed, Z. S./Laoutides, C./Gourlay, W. (2019): The Kurds in Iran. Balancing National and Ethnic Identity in a Securitised Environment. In: Third World Quarterly, 40(6): 1145-1162.

Baser, B. (2011): Kurdish Diaspora Political Activism in Europe with a Particular Focus on Great Britain. Working Paper: Berghof Peace Support/Centre for Just Peace and Democracy.

Baser, B. (2014): Diaspora Politics and Germany's Kurdish Question. University of Kent Diasporas and Security CARC Working Papers. Online: https://research.kent.ac.uk/conflict-analysis/wpcontent/uploads/sites/1511/2018/12/diaspora-politics-and-germanyskurdish-question.pdf $<15.07 .2020>$.

Baser, B./Emanuelsson, A.-C./Toivanen, M. (2015): (In)Visible Spaces and Tactics of Transnational Engagement. A Multi-Dimensional Approach to the Kurdish Diaspora. In: Kurdish Studies, 3(2), 128-150.

Bell, D./Dennen, L. (1944): The System of Governments in Exile. In: The ANNALS of the American Academy of Political and Social Science 232(1), 134-147.

Benford, R. D./Snow, D. A. (2000): Framing Processes and Social Movements. An Overview and Assessment. In: Annual Review of Sociology, 26, 611-639.

Bundesamt für Verfassungsschutz (2014): „Arbeiterpartei Kurdistans“ (PKK) strukturiert Vereine in Europa um. In: BfV-Newsletter 3/2014. Online: https://www.verfassungsschutz.de/de/oeffentlichkeitsarbeit/newsletter/news letter-archive/bfv-newsletter-archiv/bfv-newsletter-2014-3/bfv-newsletter2014-03-06.html <15.07.2020>.

Bundesamt für Verfassungsschutz (2019): Reaktionen auf das Verbot der PKKTeilorganisationen „Mezopotamien Verlag und Vertrieb GmbH“ und „MİR Multimedia GmbH“. In: BfV-Newsletter 1/2019. Online:

https://www.verfassungsschutz.de/de/oeffentlichkeitsarbeit/newsletter/news letter-archive/bfv-newsletter-archiv/bfv-newsletter-2019-01-archiv/bfvnewsletter-2019-01-thema-06 <16.07.2020>.

Bruinessen, M. v. (1991): Religion in Kurdistan. In: Kurdish Times (New York), 4(1-2), 5-27. 
Bruinessen, M. v. (1999): The Kurds in Movement. Migrations, Mobilisations, Communications and the Globalisation of the Kurdish Question. Working Paper No. 14: Islamic Area Studies Project. Online:

http://dspace.library.uu.nl/bitstream/handle/1874/20510/bruinessen_00_kur ds_in_movement.pdf?sequence $=3$ \&isAllowed $=\mathrm{y}<16.07 .2020>$.

Bruinessen, M. v. (2015): Editorial. In: Kurdish Studies, 3(2), 125-127.

Çakır-Kılınçoğlu, S. (2019): The Radicalization of the Left in Turkey and Iran in the 1970s and a Comparative Analysis of Activist Women's Experiences.

Doctoral thesis. Online: https://openaccess.leidenuniv.nl/handle/1887/82455 $<26.02 .2020>$.

Dangeleit, E. (2018): Geschenk an Erdogan? Kurdisches Kulturfestival verboten. Heise Online, 5. September 2018. Online:

https:/ / www.heise.de/tp/features/Geschenk-an-Erdogan-KurdischesKulturfestival-verboten-4155967.html <26.06.2020>.

Della Porta, D. (1995): Social Movements, Political Violence, and the State. A Comparative Analysis of Italy and Germany. Cambridge: Cambridge University Press.

Della Porta, D. (ed.) (2004): Transnational Protest and Global Activism. Lanham, MD: Rowman \& Littlefield.

Demir, I. (2012): Battling with Memleket in London. The Kurdish Diaspora's Engagement with Turkey. In: Journal of Ethnic and Migration Studies, 38(5), 815-831.

Eccarius-Kelly, V. (2002): Political Movements and Leverage Points. Kurdish Activism in the European Diaspora. In: Journal of Muslim Minority Affairs, 22(1), 91-118.

Goodwin, J./Jasper, J. M. (2006): Emotions and Social Movements. In: Stets, J. E./Turner, J. H. (eds.): Handbook of the Sociology of Emotions. Boston, MA: Springer US, 611-635.

Hourcade, B. (2009): The Rise to Power of Iran's “Guardians of the Revolution”. In: Middle East Policy, 16(3), 58-63.

Human Rights Watch (1993): Genocide in Iraq. The Anfal Campaign Against the Kurds. Online: https://www.hrw.org/reports/1993/iraqanfal/ <15.07.2020>.

Lyon, A. J./Uçarer, E. M. (2001): Mobilizing Ethnic Conflict. Kurdish Separatism in Germany and the PKK. In: Ethnic and Racial Studies, 24(6), 925-948.

McAdam, D. (1986): Recruitment to High-Risk Activism. The Case of Freedom Summer. In: American Journal of Sociology, 92(1), 64-90. 
Østergaard-Nielsen, E. (2003): The Politics of Migrants' Transnational Political Practices. In: International Migration Review, 37(3), 760-786.

Roniger, L./Sznajder, M. (2009): Introduction. The Politics of Exile. In: Roniger, L./Sznajder, M.: The Politics of Exile in Latin America. Cambridge: Cambridge University Press, 1-10.

Rosenthal, G. (2006): The Narrated Life Story. On the Interrelation between Experience, Memory and Narration. In: Milnes, K./Horrocks, C./Kelly, N./Roberts, B./Robinson, D. (eds.): Narrative, Memory \& Knowledge: Representations, Aesthetics, Contexts. Huddersfield: University of Huddersfield Press, 1-16.

Rosenthal, G. (2018): Interpretive Social Research. An Introduction. Göttingen:

Göttingen University Press. Online: https://doi.org/10.17875/gup2018-1103 $<15.07 .2020>$.

Sayigh, Y. (1987): The Politics of Palestinian Exile. In: Third World Quarterly, 9(1), 28-66.

Schamberger, K. (2020): Where Standing Up for Kurdish Rights Is a Crime. Online: https://jacobinmag.com/2020/03/germany-kurdish-repressionzozan-ypg $<26.06 .2020>$.

Smith, J. (2002): Bridging Global Divides? Strategic Framing and Solidarity in Transnational Social Movement Organizations. In: International Sociology, 17(4), 505-528.

Soleimani, K./Mohammadpour, A. (2019): The Securitisation of Life. Eastern Kurdistan under the Rule of a Perso-Shi'i State. In: Third World Quarterly, 41(4), 663-682.

Tas, L. (2017): The Influence of Diaspora Politics on Conflict and Peace.

Transnational Activism of Stateless Kurds. In: Carment, D./Sadjed, A. (eds.):

Diaspora as Cultures of Cooperation. Global and Local. Cham: Springer International Publishing, 171-198.

Thamm, A. (2019): Abgeschobener Kurde aus Nürnberg. Odyssee mit Hungerstreik. In: Taz, 16. November 2019. Online: https://taz.de/!5642346/ $<26.06 .2020>$.

Wood, E. J. (2003): Insurgent Collective Action and Civil War in El Salvador. Cambridge: Cambridge University Press.

UNPO (2020): Iranian Kurdistan. The Plight of the Kolbars. Online: https://unpo.org/article/21832<26.06.2020>. 